\title{
Polished greenstone celt caches from Ceibal: the development of Maya public rituals
}

\author{
Kazuo Aoyama ${ }^{1, *}$, Takeshi Inomata ${ }^{2}$, Flory Pinzón ${ }^{3}$ \\ \& Juan Manuel Palomo ${ }^{2}$
}

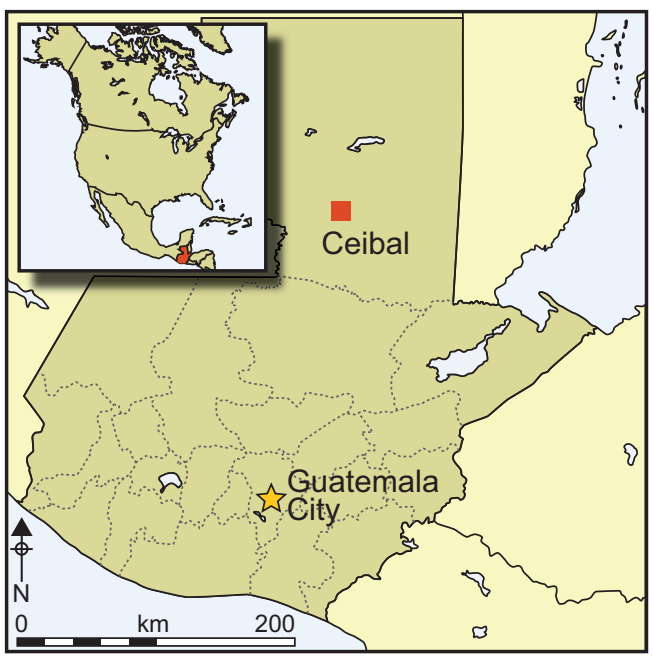

Excavations at Ceibal in Guatemala have recovered numerous polished celts from contexts dating throughout the Preclassic Maya occupation of the site. The celts are made of different types of greenstone, and most were deposited in caches in public areas close to ceremonial structures. Recent study shows how deposition practices changed over time. Furthermore, microwear analysis suggests that the majority of celts did not have a practical function. It is argued, instead, that the caches of greenstone celts represent public rituals relating to the establishment of early Preclassic elites.

Keywords: Guatemala, Ceibal, Preclassic Maya, caches, greenstone celts, public ritual

\section{Introduction}

The Middle Preclassic period (1000-350 BC) was a critical time in the development of lowland Maya civilisation, during which significant social changes took place, leading to the later emergence of divine rulership and cities. Our understanding of this period is still limited however, partly because early deposits are, typically, buried deeply under later constructions. Our excavations at Ceibal in Guatemala specifically targeted early occupation layers, revealing numerous Middle Preclassic caches containing polished greenstone celts in the Central Plaza. Use-wear analysis with a high-power microscope suggests that many of the celts were made specifically for ritual purposes, although a smaller number of them

\footnotetext{
Faculty of Humanities, Ibaraki University, Bunkyo 2-1-1, Mito, Ibaraki 310-8512, Japan

School of Anthropology, University of Arizona, 1009 E South Campus Drive, Tucson AZ 85719, USA

Proyecto Arqueológico Ceibal-Petexbatun, Guatemala City, Guatemala

Author for correspondence (Email: kazuo.aoyama.1@vc.ibaraki.ac.jp)
}

(C) Antiquity Publications Ltd, 2017. This is an Open Access article, distributed under the terms of the Creative Commons Attribution-NonCommercial-ShareAlike licence (http://creativecommons.org/licenses/ by-nc-sa/4.0/), which permits noncommercial re-use, distribution, and reproduction in any medium, provided the same Creative Commons licence is included and the original work is properly cited. The written permission of Cambridge University Press must be obtained for commercial re-use. 


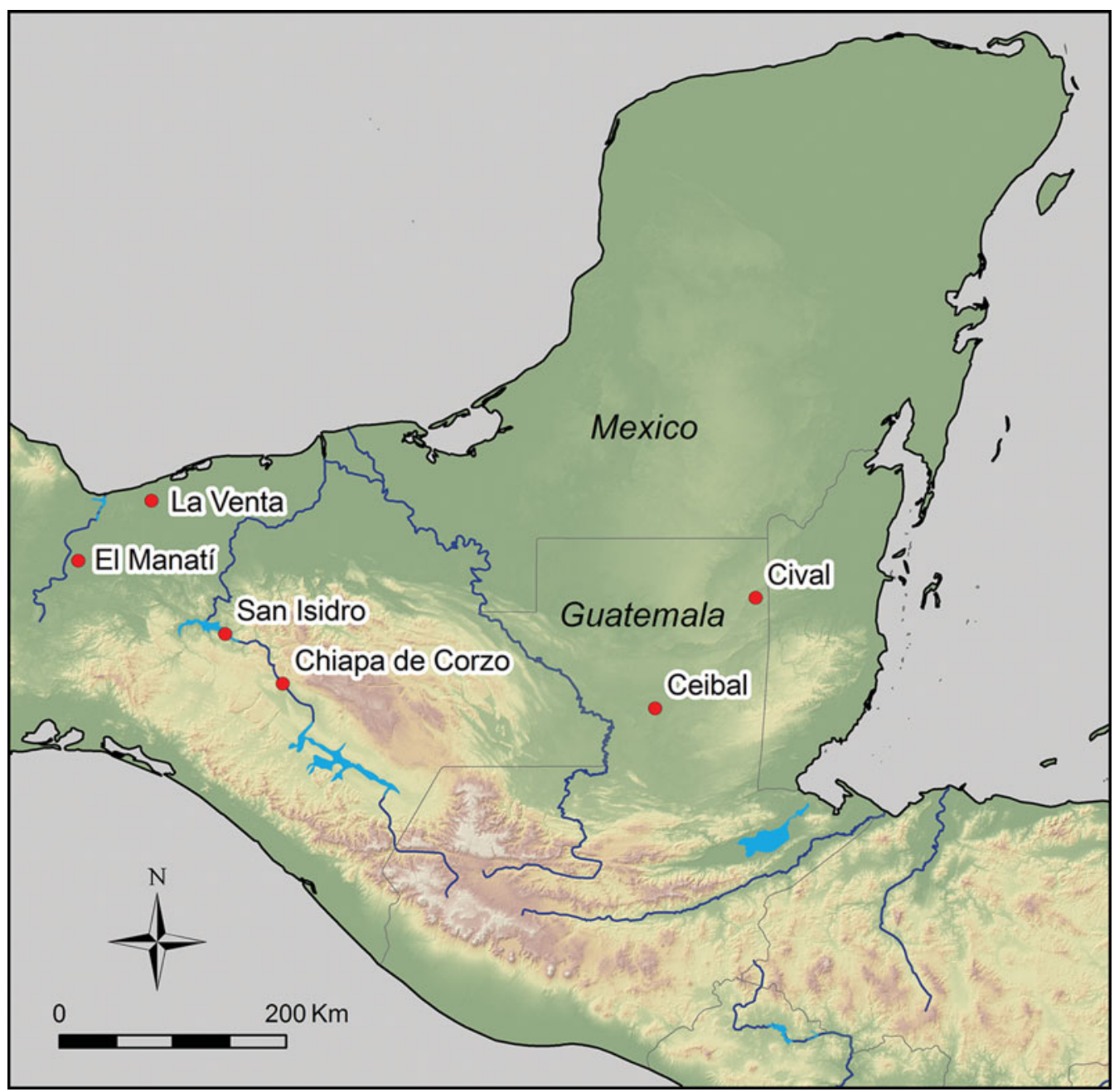

Figure 1. Map of southern Mesoamerica showing the locations of Ceibal and the sites discussed in the text.

were used for wood carving. The significant number of these deposits in the public plaza points to the importance of public events for the integration of the community and for political negotiation involving emerging elites and other diverse community members. The emerging elite probably played a primary role in these rituals, setting a template for late public events centred on rulers.

\section{The site}

The lowland Maya city of Ceibal (also spelled Seibal), Guatemala, is the largest among the Pasion River drainage sites, both in extent and in the total volume of major public structure construction (Figure 1). This site is well known for the landmark investigation conducted (C) Antiquity Publications Ltd, 2017 
by Harvard University from 1964-1968 (Sabloff 1975; Willey 1990). Building on this pioneering work, intensive excavations of the Ceibal-Petexbatun Archaeological Project have uncovered substantial construction activities in the early stages of human settlement at Ceibal, especially during the Middle Preclassic period. The centre of Ceibal represents the earliest known formal ceremonial complex with an E-Group temple. This is identified as a square structure on the west side of the public plaza, with an elongated platform to the east of the E-Group temple assemblage. The ceremonial complex was constructed on top of the slope $100 \mathrm{~m}$ above the Pasion River around 1000 BC (Inomata et al. 2013, 2015).

\section{Methodology}

The Ceibal-Petexbatun Archaeological Project uncovered 18 caches $(\mathrm{N}=64)$, one grave $(\mathrm{N}=1)$ and seven secondary contexts $(\mathrm{N}=7)$ that contained a total of 72 polished greenstone celts, i.e. the largest number of greenstone celts dating to the Middle Preclassic period in a single site in the Maya lowlands so far. Sixteen caches were from the east-west axis of the E-Group plaza, while the other two caches were found in the A-24 platform (Figures $2 \& 3$ ). Before our investigation, only a few greenstone celts pertaining to the period corresponding to the Real 3 phase (775-700 BC) of the Ceibal chronology had been uncovered in the Maya lowlands at Ceibal ( $\mathrm{N}=7$, Smith 1982: 118) and Cival, also in Guatemala ( $N=5$, Estrada-Belli 2006: 61), which were deposited in cruciform arrangements.

The archaeological context and cultural significance of 13 of the caches with greenstone celts, discovered by 2012, have been reported by Inomata and Triadan (2016). This article focuses on the results of lithic analysis and also reports six celt-containing caches and other deposits found during the 2013 and 2015 field seasons by the present authors (Palomo and Pinzón). Apart from typological classification, identification of lithic raw materials and the measurement of various physical attributes, one of the authors (Aoyama) conducted the first ever microwear analyses on the Preclassic Maya polished greenstone celts based on the high-power microscopy approach. In 1987, he conducted an intensive experimental study of use-wear on obsidian and chert artefacts in Honduras in order to establish a framework for the interpretation of Maya stone tool use (Aoyama 1999). The results of 267 replication experiments conducted on a range of worked materials permitted the identification of use-wear patterns. Comparison of microwear on the Preclassic Maya polished greenstone celts with published experimental use-wear data on replica polished celts made from greenstone, including serpentine (e.g. Takase 2007; Yamada 2014), made it possible for Aoyama to identify a diagnostic wood polish; an authentic Type B polish on chert artefacts, which is one of the 11 basic polish types (Aoyama 1999: 39). The surface of Type B polish is smooth, rounded and bright. Moreover, the development of a large 'patchlike' polish structure is totally different from other types of polish, such as use-wear from working with leather. The instrument used in the study was a metallurgical microscope (Olympus BX60M) with 50-500× magnification and an incident-light attachment. The experiments with replica polished celts made from jade were needed to understand the function of greenstone polished celts. 


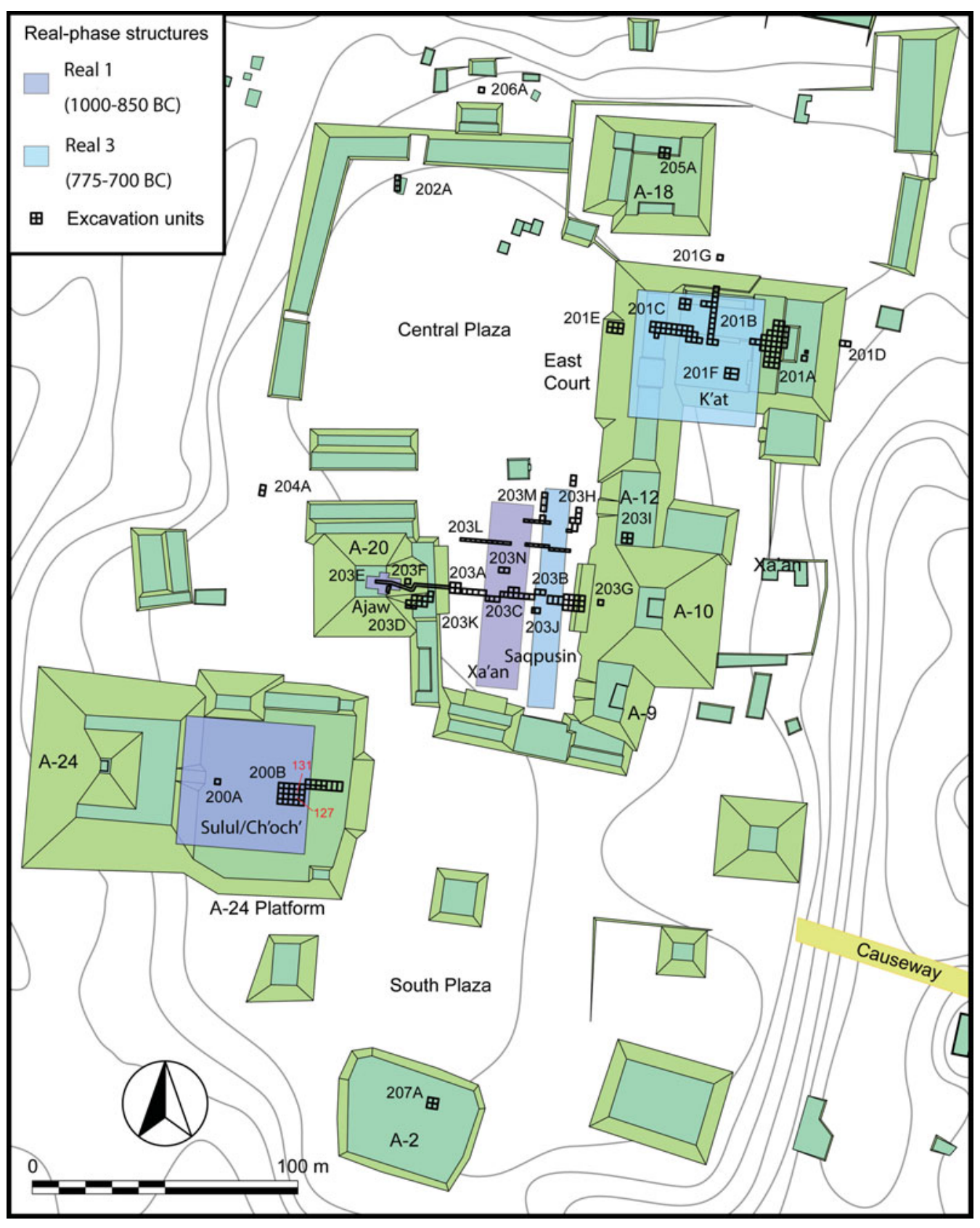

Figure 2. Map of group A at Ceibal with the locations of the Middle Preclassic polished greenstone celt caches (drawing by Takeshi Inomata). The excavation units that located the caches are shown. The red numbers refer to the caches.

(C) Antiquity Publications Ltd, 2017 
Table 1. Typology of greenstone celts from Middle Preclassic Ceibal.

\begin{tabular}{lccccc}
\hline Phase & Large & Medium & Small & Very small & Total \\
\hline & & & & & \\
Real 1 & 9 & 4 & 5 & 0 & 18 \\
Real 2 & 0 & 2 & 10 & 7 & 19 \\
Real 3 & 0 & 0 & 7 & 4 & 11 \\
Real (secondary contexts) & 0 & 0 & 1 & 1 & 2 \\
Escoba 1 & 0 & 1 & 4 & 5 & 10 \\
Escoba 2 & 0 & 0 & 5 & 2 & 7 \\
Escoba (secondary contexts) & 0 & 1 & 1 & 3 & 5 \\
Total & $\mathbf{9}$ & $\mathbf{8}$ & $\mathbf{3 3}$ & $\mathbf{2 2}$ & $\mathbf{7 2}$ \\
\% & $\mathbf{1 2 . 5}$ & $\mathbf{1 1 . 1}$ & $\mathbf{4 5 . 8}$ & $\mathbf{3 0 . 6}$ & \\
\hline
\end{tabular}

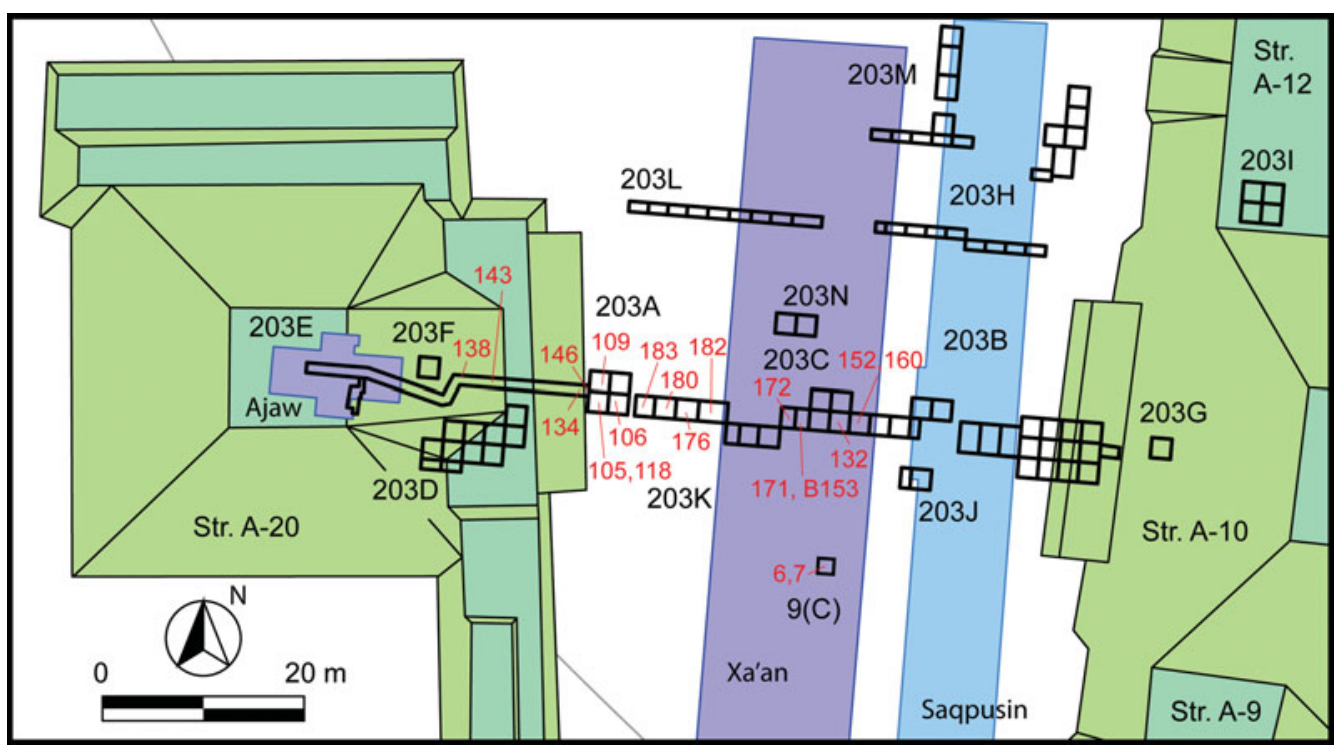

Figure 3. Close-up of the E-Group plaza at Ceibal with the locations of the Middle Preclassic polished greenstone celt caches (drawing by Takeshi Inomata). The excavation units that located the caches are shown. The red numbers refer to the caches.

Among the items highly prized by pre-Columbian Mesoamerican people were objects carved in hard greenstone. The polished greenstone celts from Ceibal were manufactured from jade (29.2 per cent), metagabbro (11.1 per cent), serpentine (4.2 per cent) and other metamorphic greenstone (55.6 per cent). These lithic raw materials were all imported from the Guatemalan highlands. The colour of greenstone itself may have had a ritual significance. In the Yucatec Maya codices, the colour green is associated with the centre of the world (Miller \& Taube 1993: 65). Except for two distal fragments, a medial fragment and three proximal fragments, 65 celts are complete and one is nearly complete. As shown in Table 1, they were subdivided based on length following the neighbouring site of Aguateca's (Aoyama 2009: 48) categories of large (100mm and above), medium (80-100mm), small 
$(50-80 \mathrm{~mm})$ and very small $(<50 \mathrm{~mm})$. Polished greenstone celts from primary contexts are discussed in detail below by phases. The results of microwear analysis indicate that use-wear was observed on ten small celts and six very small celts, while no large and medium celts were used.

\section{Real 1 phase (1000-850 BC)}

Four caches dating from the Real 1 phase containing polished greenstone celts (caches 118, 134,138 and 183) came from the east-west axis of the E-Group plaza. A series of greenstone celts and other caches were deposited in this public plaza, indicating that this space served as a stage for public performance throughout the Middle Preclassic period. At the beginning of the Real 1 phase (c. $1000 \mathrm{BC}$ ), the residents of Ceibal dug a pit into the initial plaza floor between the first two ceremonial structures (structure Ajaw on the west side, and structure Xa'an on the east side) and deposited cache 118, consisting of the largest number of greenstone celts $(\mathrm{N}=12)$ as part of public rituals. Both the mean dimensions and mean weight of the celts from cache 118 are well above those of the Middle Preclassic period (Table 2). Eight large celts, three medium celts and a small celt were placed horizontally. Ten of them rested in two parallel lines and a large celt made from serpentine was placed in front of them, while a small jade celt was deposited $100 \mathrm{~mm}$ above them. Two of the ten celts laid in the two parallel lines are large: more than $150 \mathrm{~mm}$ in length, and include the largest polished greenstone celt ever found at Ceibal to date $(165 \times 73 \times 32 \mathrm{~mm}$, 610.9g).

Cache 134 was uncovered $2 \mathrm{~m}$ to the west of cache 118 . A large jade celt was placed upright in a pit, which was also dug into the first plaza floor at the beginning of the Real 1 phase. Its proximal end was planted in the ground and the distal end pointed upward. This special placement of axes and bundles of axes grouped together, as well as those rested like petals of a flower (see below), closely resemble those found at El Manatí during the Manatí B phase (1500-1200 BC), suggesting that the residents of Ceibal adopted ritual practices involving the deposition of greenstone celts that had originated in the Isthmian region, including the southern Gulf Coast (Ortiz \& Rodríguez 2000). Both caches 118 and 134 consisted of the earliest greenstone celts ever found in the Maya lowlands to date. The celt from cache 134 shows faceting with a circular dimple not apparent on any of the other celts recovered from Ceibal. The dimple was clearly intentionally created by the knapper. This feature is identical to two faceted celts found in offering 1942-C at the Middle Preclassic Olmec centre of La Venta (Drucker et al. 1959: fig. 65; Inomata $\&$ Triadan 2016). Nevertheless, the Ceibal faceted celt belongs to the Real 1 phase, and is earlier than the La Venta celts, which pertain to the Real 3 phase or later. The results of microwear analysis on the 12 celts from cache 118 and on the large jade celt from cache 134 indicate that none of them were used.

Cache 138 was located in the second floor of the E-Group plaza, and dates to later than caches 118 and 134. Four small celts appear to have been placed in a circle and their distal ends were pointed upward, like the petals of a flower. The mean dimensions and mean weight of cache 138 are much smaller than those of caches 118 and 134 (Table 2). One celt was manufactured from jade, while the other three were made from a different type of (C) Antiquity Publications Ltd, 2017 
Table 2. Complete greenstone celts from the Middle Preclassic caches at Ceibal.

\begin{tabular}{|c|c|c|c|c|c|c|c|c|c|}
\hline \multirow[b]{2}{*}{ Cache } & \multicolumn{2}{|c|}{$\begin{array}{l}\text { Length } \\
(\mathrm{mm})\end{array}$} & \multicolumn{2}{|c|}{$\begin{array}{l}\text { Width } \\
(\mathrm{mm})\end{array}$} & \multicolumn{2}{|c|}{$\begin{array}{l}\text { Thickness } \\
(\mathbf{m m})\end{array}$} & \multicolumn{2}{|c|}{$\begin{array}{l}\text { Weight } \\
\text { (g) }\end{array}$} & \multirow[b]{2}{*}{ Number } \\
\hline & Mean & SD & Mean & SD & Mean & SD & Mean & SD & \\
\hline $\begin{array}{l}\text { Cache } 118 \text { (CB203A-1-9-3), } \\
\quad \text { Real } 1\end{array}$ & 114 & 29 & 52 & 12 & 24 & 5 & 266.1 & 138.6 & 12 \\
\hline $\begin{array}{l}\text { Cache } 134 \text { (CB203 E-1-9-1), } \\
\text { Real } 1\end{array}$ & 101 & - & 49 & - & 27 & - & 212.6 & - & 1 \\
\hline $\begin{array}{l}\text { Cache } 138 \text { (CB203 E-1-9-2), } \\
\text { Real } 1\end{array}$ & 66 & 4 & 38 & 4 & 18 & 4 & 74.9 & 22.8 & 4 \\
\hline $\begin{array}{l}\text { Cache } 109 \text { (CB203 A-2-8-2), } \\
\text { Real } 2\end{array}$ & 48 & 8 & 35 & 8 & 15 & 6 & 55.3 & 36.3 & 4 \\
\hline $\begin{array}{l}\text { Cache } 127 \text { (CB200B-16-9-6), } \\
\quad \text { Real } 2\end{array}$ & 60 & 10 & 35 & 5 & 17 & 5 & 70.7 & 24.5 & 3 \\
\hline $\begin{array}{l}\text { Cache } 131 \text { (CB200B-19-10-2), } \\
\text { Real } 2\end{array}$ & 82 & - & 44 & - & 26 & - & 132.7 & - & 1 \\
\hline $\begin{array}{l}\text { Cache } 143 \text { (CB200 E-1-8-12), } \\
\text { Real } 2\end{array}$ & 58 & 15 & 35 & 4 & 15 & 2 & 59.0 & 26.4 & 8 \\
\hline $\begin{array}{l}\text { Cache } 146 \text { (CB203 E-1-8-13), } \\
\text { Real } 2\end{array}$ & 56 & - & 36 & - & 17 & - & 65.3 & - & 1 \\
\hline $\begin{array}{l}\text { Cache } 132 \text { (CB200 C-3-7-2), } \\
\text { Real } 3\end{array}$ & 50 & 8 & 36 & 5 & 17 & 5 & 70.7 & 24.5 & 5 \\
\hline $\begin{array}{l}\text { Cache } 160 \text { (CB200 B-20-8-6), } \\
\text { Real } 3\end{array}$ & 59 & 9 & 33 & 4 & 15 & 2 & 54.0 & 13.5 & 5 \\
\hline $\begin{array}{l}\text { Cache } 182 \text { (CB200 K-6-7-8), } \\
\text { Real } 3\end{array}$ & 52 & - & 25 & - & 12 & - & 30.7 & - & 1 \\
\hline $\begin{array}{l}\text { Cache } 106 \text { (CB203A-3-6-5), } \\
\text { Escoba } 1\end{array}$ & 66 & - & 39 & - & 9 & - & 37 & - & 1 \\
\hline $\begin{array}{l}\text { Cache } 152 \text { (CB203 B-20-6-6), } \\
\text { Escoba } 1\end{array}$ & 44 & - & 37 & - & 17 & - & 40 & - & 1 \\
\hline $\begin{array}{l}\text { Cache } 171 \text { (CB200 K-1-10-6), } \\
\text { Escoba } 1\end{array}$ & 55 & 21 & 32 & 7 & 13 & 3 & 42.2 & 24.9 & 7 \\
\hline $\begin{array}{l}\text { Cache } 172 \text { (CB200 K-2-7-6), } \\
\text { Escoba } 1\end{array}$ & 52 & - & 32 & - & 12 & - & 40.5 & - & 1 \\
\hline $\begin{array}{l}\text { Cache } 105 \text { (CB203A-1-6-4), } \\
\text { Escoba } 2\end{array}$ & 55 & 9 & 34 & 1 & 16 & 2 & 47.6 & 7.3 & 2 \\
\hline $\begin{array}{l}\text { Cache } 176 \text { (CB203K-7-7-2), } \\
\text { Escoba } 2\end{array}$ & 66 & - & 36 & - & 21 & - & 85.2 & - & 1 \\
\hline $\begin{array}{l}\text { Cache } 180 \text { (CB203K-8-7-3), } \\
\text { Escoba } 2\end{array}$ & 50 & 9 & 30 & 13 & 16 & 8 & 56.4 & 53.6 & 3 \\
\hline All complete celts & 67 & 29 & 37 & 11 & 17 & 6 & 96.6 & 106.2 & 65 \\
\hline
\end{tabular}

greenstone. One of the other three celts made from a different type of greenstone placed on the east side had been employed for wood carving. Type B polish, produced as the result of wood working (Aoyama 2009: 12), and vertical striations were observed on its distal end, indicating wood chopping. This is the only polished greenstone celt that had been used (5.6 per cent) of the Real 1 phase's celts. By contrast, the residents of Ceibal did not 
Table 3. Mean length of complete polished greenstone celts from the Middle Preclassic Ceibal.

\begin{tabular}{lcccc}
\hline & Mean $(\mathbf{c m})$ & SD $(\mathbf{c m})$ & Range $(\mathbf{c m})$ & N \\
\hline Real 1 & & & & \\
Real 2 & 10.2 & 3.3 & $5.5-16.5$ & 17 \\
Real 3 & 5.7 & 1.5 & $3.8-8.7$ & 17 \\
Escoba 1 & 5.4 & 0.9 & $4-7.1$ & 11 \\
Escoba 2 & 5.5 & 1.8 & $3.8-9.4$ & 10 \\
All & 5.5 & 1.0 & $4.2-6.6$ & 6 \\
\hline
\end{tabular}
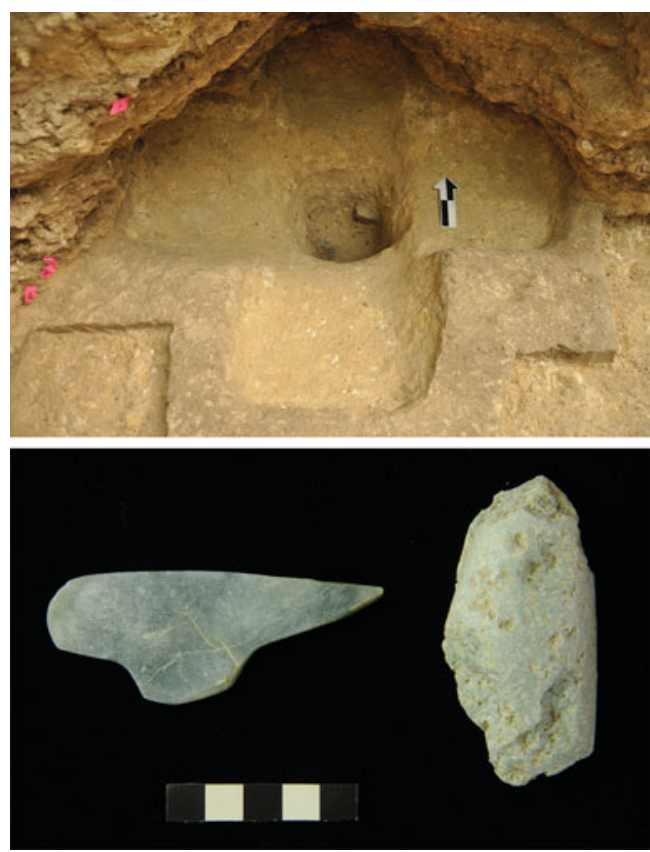

Figure 4. Cache 183. Top: photograph taken during excavation. Note that we had excavated the area outside the cache to a lower level, leaving the original floor around the cruciform edge of the cache (photograph by Flory Pinzón). Bottom: the offerings deposited within cache 183 (photograph by Takeshi Inomata). use the great majority of greenstone celts as utilitarian tools, but rather deposited them in caches in the public plaza during this phase.

Cache 183 itself was deposited in a cruciform arrangement. Both an unfinished jade spoon of a style usually attributed to the Middle Preclassic Gulf Cost Olmec and a medial fragment of medium-sized jade celt with no use-wear were deposited in its central part (Figure 4), unlike the later cruciform caches with celts placed in radiating arms of the pits (see below). The cache was sealed by floor 20 , which we date to the Real 1 phase. If this dating is correct, cache 183 represents the earliest cruciform cache found in southern Mesoamerica, possibly signalling the development of new ritual practice. According to iconographic studies, polished greenstone celts in cruciform patterns were associated with maize ears as well as lightning, and were imbued with divine power, often as symbols of the world axis (Taube 2000).

\section{Real 2 phase (850-775 BC)}

Four caches date to the Real 2 phase, while one dates (cache 143) to the Real 2-3 transition. Three of these caches (caches 109, 143 and 146) were found in the east-west axis of the E-Group plaza, and two caches (caches 127 and 131) were found in the A-24 platform. Compared with the polished greenstone celts of the Real 1 phase, the celts of the Real 2 phase were smaller (Table 3), and 5 out of 18 finished celts placed in the five caches (27.8 per cent) were used for carving wood before their deposition in caches (Figure 5).

(C) Antiquity Publications Ltd, 2017 


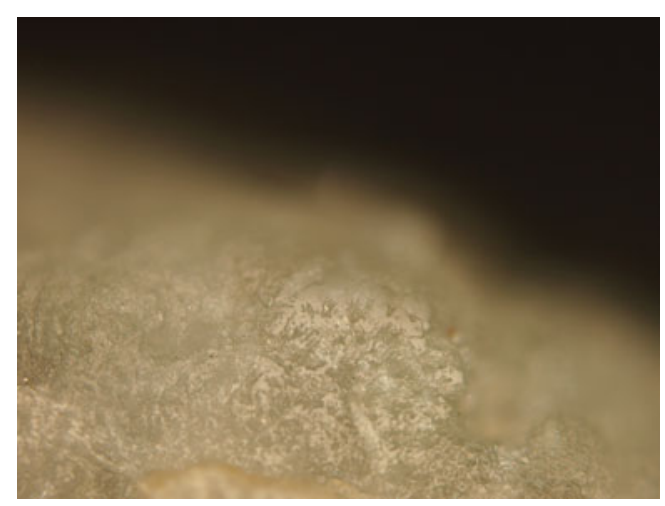

Figure 5. B-type polish and vertical striations on a polished greenstone celt used to carve wood, from cache 109 of Ceibal, Real 2 phase (200× magnification) (photograph by Kazuo Aoyama).
Cache 109 consisted of seven objects: four complete celts, a nearly complete celt, a distal fragment of celt and an unfinished jade object reworked from a rectangularshaped ornament, which could refer to a symbolic celt. Six of them were arranged irregularly in an open semicircle with their distal ends pointing upward and proximal ends down, while the distal fragment was placed horizontally above them. Four complete celts-one small celt and one very small celt made from a different type of greenstone, as well as two very small celts manufactured from metagabbro (Figure 6: 5)—were employed for wood carving. Cache 146 contained a small celt made from a different type of greenstone, which was also used for wood carving. Cache 143 consisted of eight polished greenstone celts placed in a loose cruciform arrangement. The eight celts include: a medium jade celt, two small celts made from the translucent 'Olmec' blue-green jade found among the Gulf Coast Olmec (Seitz et al. 2001), one small celt and two very small celts manufactured from metagabbro, as well as one small celt and one very small celt made from a different type of greenstone. The results of microwear analysis suggest that none of them were used.

Extensive excavation of Platform Ch'och' (an early version of the A-24 platform) revealed two greenstone celt caches. It is not clear whether this platform served as an elite residence complex during the Real 2 phase or not. Cache 131 comprised an unfinished greenstone celt (Figure 6: 1) and was placed in horizontal alignment with overlying floor 8. Several flakes were removed by striking a metagabbro nodule. Both surfaces mostly show remnant natural cortex, while the distal area was partially polished thus forming a cutting edge. No use-wear was observed on it.

Cache 127 comprised three small celts, which appear to have been originally positioned upright and were of a triangular shape, with the proximal ends in the ground and the distal ends pointing upward. Cache 127 was uncovered under floor 7a1 in platform Ch'och' slightly later than cache 131 (Figure 2). One celt was manufactured from jade, while the others were made from a different type of greenstone. The results of microwear analysis show that none of them were used. No greenstone celts have been found in any other Middle Preclassic residence at Ceibal. If platform Ch'och' was a residential complex, caches 127 and 131 represent the first and only examples of the Middle Preclassic greenstone celt caches found in domestic contexts in the Maya lowlands to date. Although the nature of platform Ch'och' remains ambiguous, we may consider the possibility that the emergent elites played an important role in the exchange of greenstone nodules and finished celts, as well as in celt production and use, and in addition to their deposition during public rituals held in the E-Group plaza at Ceibal.

(C) Antiquity Publications Ltd, 2017 


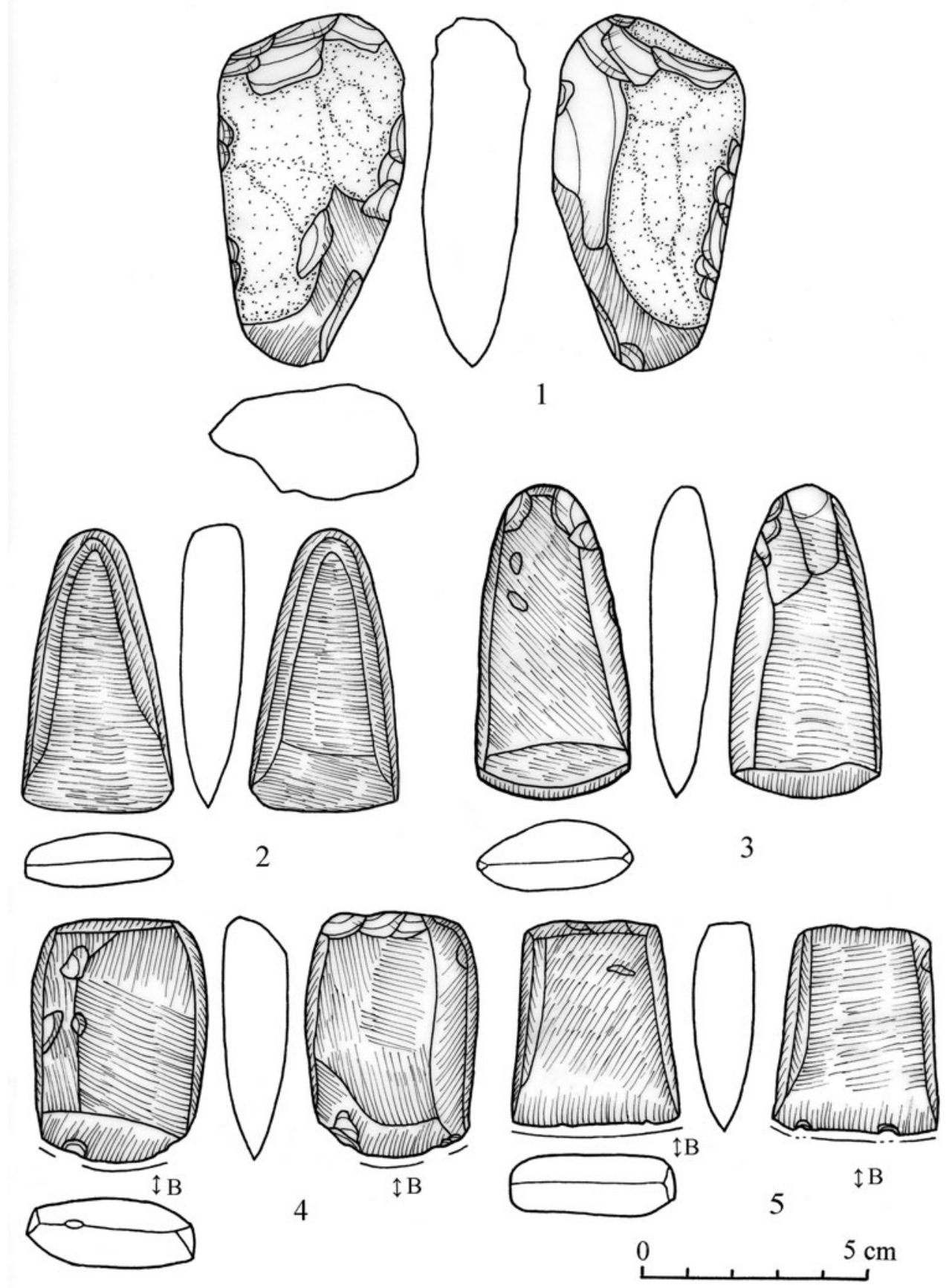

Figure 6. Polished greenstone celts of the Middle Preclassic Ceibal: 1) unfinished celt (cache 131, Real 2 phase); 2) unused small celt (cache 105, Escoba 2 phase); 3) unused small celt (cache 160, Real 3 phase); 4) small celt used for wood carving (cache 132, Real 3 phase); 5) very small celt used for wood carving (cache 109, Real 2 phase). Celts 4-5 show the distribution of use-wear associated with Type B polish and vertical striations (drawing by Kazuo Aoyama).

(C) Antiquity Publications Ltd, 2017 


\section{Real 3 phase (775-700 BC)}

Three caches (caches 132, 160 and 182) containing polished greenstone celts, recovered from the east-west axis of the E-Group plaza, date to the Real 3 phase. Excavators did not recognise a circular pit of cache 132 until they reached the natural marl layer. The pit may have been cut from floors 7,8 or $8 \mathrm{~b}$. Given its similarity to cache 160 uncovered $1.7 \mathrm{~m}$ to the east of cache 132 , we tentatively assume that cache 132 is roughly contemporaneous with the nearby cache 160 . Five out of eleven celts ( 45.5 per cent) were employed for carving wood before their deposition in caches. Caches 132 and 160 were deposited in cruciform arrangements that closely resemble those found at Chiapa de Corzo (Bachand 2013), San Isidro (Lowe 1981), La Venta (Drucker et al. 1959) and Cival (Estrada-Belli 2006), suggesting that elites at Ceibal shared ritual practices with those of neighbouring centres, possibly through direct contact. Cache 132 contained five polished greenstone celts. The northern and western celts seem to have been arranged pointing upward with their proximal ends in the ground, while the central celt was placed flat with its distal end pointing east. The other two celts seem to have been moved from their original position. The results of microwear analysis indicate that three celts, i.e. the eastern (Figure 6: 4) and northern small celts (made from metagabbro) as well as the very small, western celt, manufactured from a different type of greenstone, were used for wood carving.

Cache 160 also contained five greenstone celts in a cruciform deposit. The central small celt manufactured from jade was placed flat with its distal end pointing north, and was found in association with a small quartz sphere and a small quantity of red pigment in the central part of the pit. Each of the other four celts, made from other unidentified greenstone, were placed upright in cardinal directions relative to the central jade piece. The very small, northern celt and small southern celt were employed for carving wood. Cache 182 contained a single small celt manufactured from a different type of greenstone with no evidence of use-wear.

\section{Escoba 1 phase (700-600 BC)}

At the beginning of the Escoba 1 phase, the residents of Ceibal dug a pit to place cache 171 in the east-west axis of the E-Group plaza. It was cruciform in shape and oriented to the four points of the Maya cosmos, similar to the earlier cruciform caches. A pectoral (chest ornament) and an 'icepick-form' perforator, both made from translucent 'Olmec' bluegreen jade, a greenstone celt and a polishing stone made of sandstone were placed in the central part of the pit (Figure 7). The 'icepick-form' perforator may have been an import from the Gulf Coast. A pottery vessel and a greenstone celt were deposited in the east part; and a pottery vessel, a greenstone celt, a green polishing stone and a pyrite mirror in the west; a pottery vessel and two greenstone celts in the south and two greenstone celts were deposited in the north. The seven celts mentioned above include: a medium serpentine celt, two very small celts made from jade, two small celts and two very small celts manufactured from a different type of greenstone. Among them, a small celt made from a different type of greenstone was used for wood carving. These celts were found laid flat in horizontal 

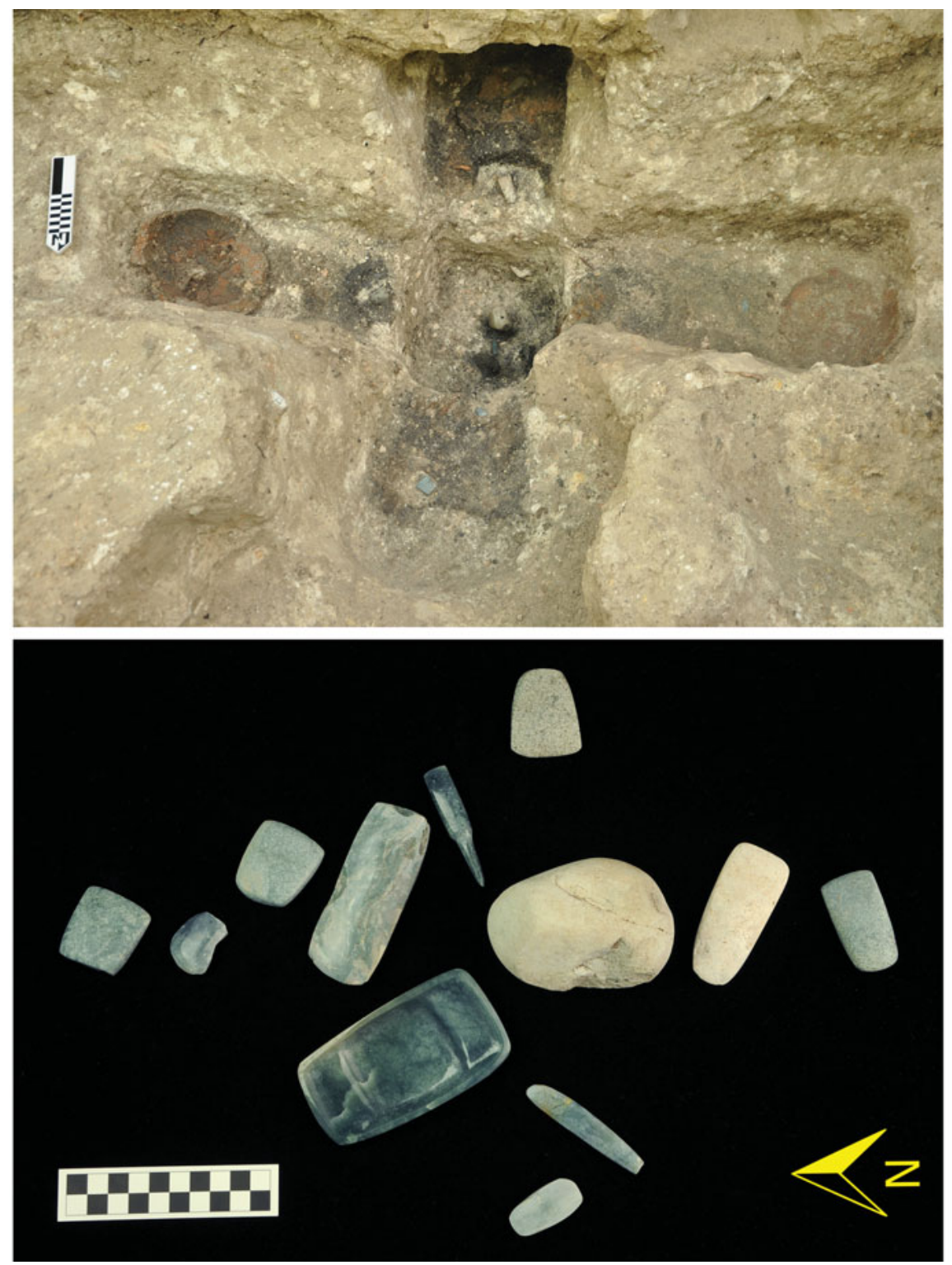

Figure 7. Cache 171. Top: photograph taken during excavation. The dark soil probably resulted from intense burning (photograph by Flory Pinzón). Bottom: the loosely approximated relative positions of the offerings, with north to the viewer's left (photograph by Takeshi Inomata).

positions, and it is not clear whether any of them were originally placed vertically on their proximal ends.

During the latter part of the late Middle Preclassic period, after the beginning of the Escoba 1 phase, the number of greenstone celts deposited in caches decreased. Three more caches pertaining to the Escoba 1 phase were found from the east-west axis of the E-Group plaza. Cache 106 contained a small celt made from a different type of greenstone without (C) Antiquity Publications Ltd, 2017 

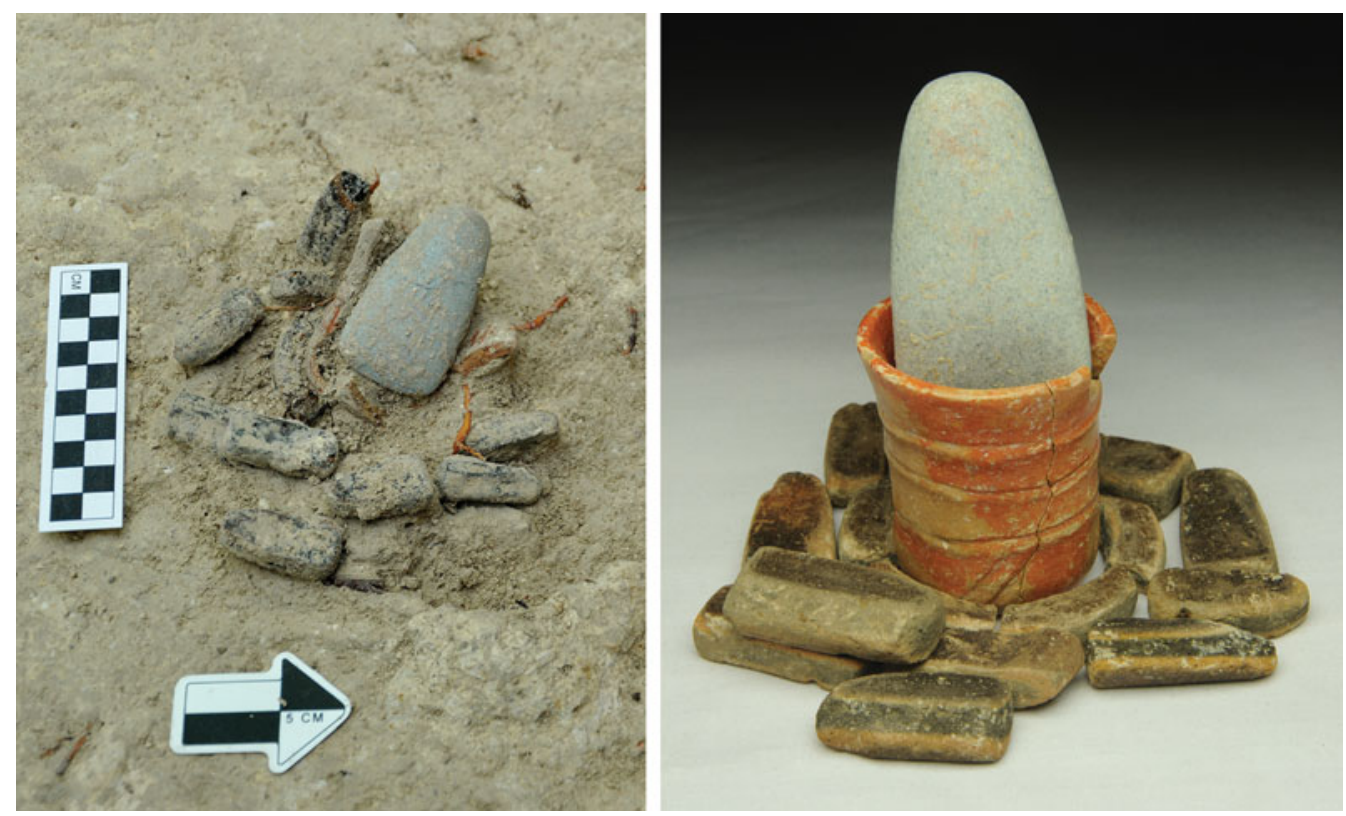

Figure 8. Cache 176. Left: photograph taken during excavation (photograph by Flory Pinzón). Right: reconstruction of the original arrangement of the offerings (photograph by Takeshi Inomata).

any evidence of use-wear. Cache 152 yielded a very small, unfinished jade celt. A jade pebble that had been flaked and then polished, but with remnant flake scars left unpolished, was also recovered. No use-wear traces were observed on it. In Cache 172, a small jade celt without any evidence of use-wear was placed in association with burnt sherds of a partial ceramic jar (Achiotes Unslipped).

\section{Escoba 2 phase (600-450 BC)}

During the Escoba 2 phase, between one and three celts were deposited in each of three caches (caches 105, 176 and 180) and a burial (burial 153) on the east-west axis of the E-Group plaza (Table 2). Cache 105 contained two celts: one small and made from the translucent 'Olmec' blue-green jade, and the other very small and manufactured from a different type of greenstone. The latter was employed for wood carving. A small celt made from a different type of greenstone as well as a miniature pottery vessel and 15 small pieces of reworked ceramic sherds were placed in cache 176 (Figure 8). No evidence of use-wear was observed on the celt.

Cache 180 was cruciform in shape (Figure 9). Two celts - a small jade celt and a small celt made from a different type of greenstone, as well as a very large, mostly unworked piece of obsidian (the largest piece ever found at Ceibal, 245.4g)—were placed in the central part of the pit. A very small celt manufactured from a different type of greenstone was deposited to the south of the pit. The results of microwear analysis indicate that the two celts placed in the central part of the pit were used for wood carving. Both greenstone celts and the very

(C) Antiquity Publications Ltd, 2017 


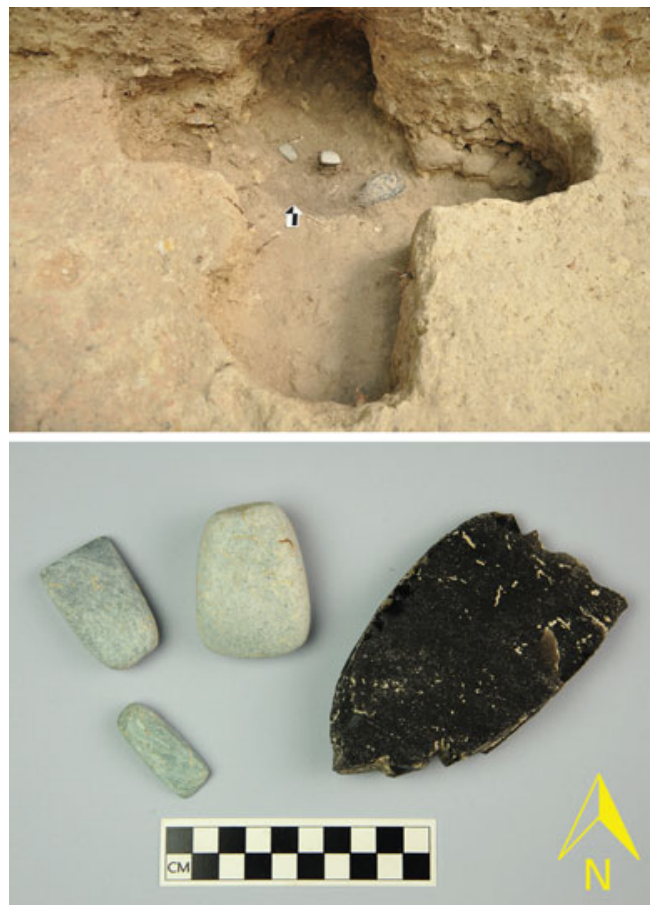

Figure 9. Cache 180. Top: photograph taken during excavation (photograph by Flory Pinzón). Bottom: approximate relative positions of the offerings, with north to the top of the image (photograph by Takeshi Inomata). large, nearly unworked obsidian appear to have had some ritual significance for the residents of late Middle Preclassic Ceibal.

Burial 153 consisted of the sacrificed remains of five individuals, with one placed at each of the cardinal points (i.e. the bodies were oriented towards the cardinal directions) and the fifth between the south and west human remains. Four of the individuals were infants less than one year old, while the fifth was an infant three to four years old. A total of five exhausted polyhedral cores of obsidian, one for each of the four sacrificial individuals, and one placed in their centre, were also submitted as offerings. There was also a proximal fragment of greenstone celt associated with the human remains to the north, a jade bead for each of the other three individuals and a blue polishing stone in the centre. Here, the fragment of greenstone celt was not a centrepiece of the burial offering. Moreover, this is, to date, the only burial found to contain a greenstone celt at Ceibal. The ritual significance of greenstone celts appears to have diminished by the Escoba 2 phase. Exhausted polyhedral obsidian cores and pressure-flaked blades were more frequently left as caches and burial offerings in the public plaza during the Escoba 3 phase (450-350 BC).

\section{Discussion}

At the beginning of the Real 1 phase, the Ceibal residents deposited the largest number of greenstone celts below the first public plaza, including the largest ones at Ceibal, as part of public rituals. Notably, no large celts were found in the following periods (Table 1). The mean length of complete celts of the Real 1 phase is considerably greater than those of the subsequent periods (Table 3). Polished celts were manufactured from metagabbro and jade at Ceibal during the Middle Preclassic period. Some of the polished celts may have been imported to Ceibal as finished artefacts, as indicated by the absence of any manufacturing debris of the translucent 'Olmec' blue-green jade, serpentine and a different type of greenstone. A decrease in the number of celts in caches is noteworthy during the Escoba phase. Towards the end of the Middle Preclassic period, common forms of ritual deposits in the public plaza shifted from greenstone celt caches to those of ceramic vessels and sacrificial human remains (Inomata 2014: 22), as well as other artefacts such as exhausted polyhedral cores of obsidian.

(C) Antiquity Publications Ltd, 2017 


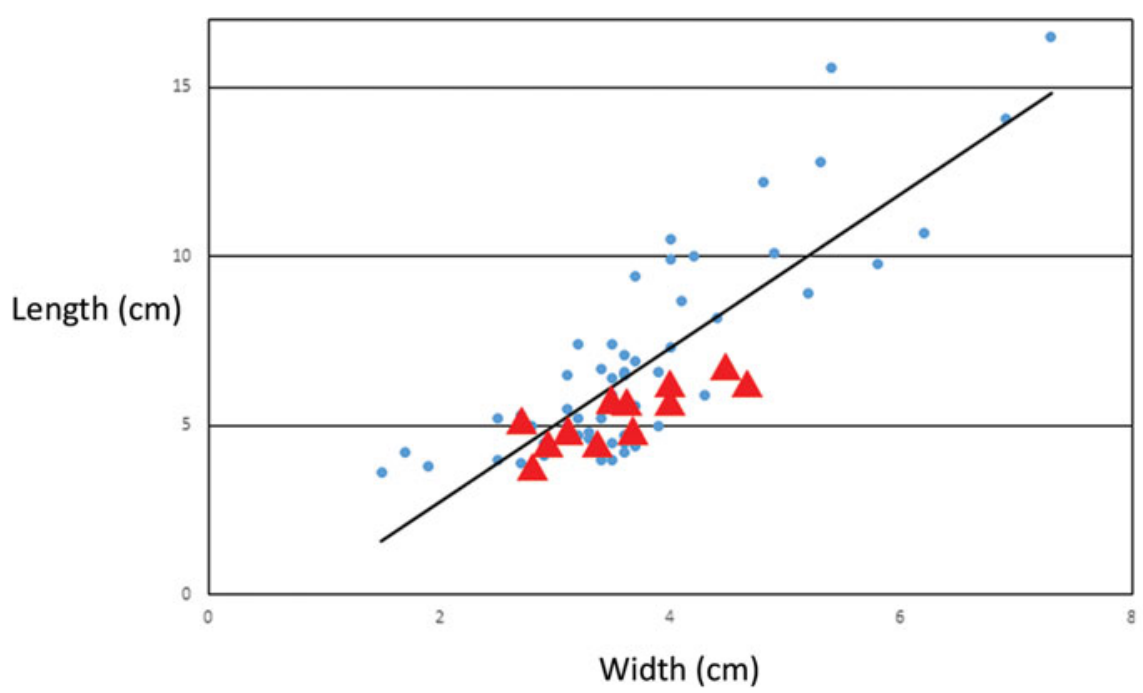

Figure 10. The length-to-width ratio of the used polished greenstone celts from Ceibal during the Middle Preclassic period. $\boldsymbol{\Delta}=$ used celts, $\bullet=$ unused celts and the line represents simple linear regression.

It is significant that all greenstone celts with evidence of use-wear from the Middle Preclassic period had been used specifically for wood carving. Excluding a medial fragment and three proximal fragments, use-wear was observed on 16 out of 68 celts $(23.5$ per cent). Among the 63 celts deposited in the caches, 15 ( 23.8 per cent) had been used. The residents of Ceibal deposited the great majority of unused greenstone celts in the caches in the public plaza during the Real 1 phase. After that phase, more celts were used for carving wood prior to their deposition in the caches. When divided according to raw material composition, the sample of celts bearing traces of use-wear comprised four metagabbro celts, two jade celts and ten other greenstone celts. No use-wear was observed on the serpentine or the translucent 'Olmec' blue-green jade celts. Some if not all of the translucent 'Olmec' blue-green jade celts may have been imports from the Gulf Coast. Significantly, no large or medium celts bore evidence of having been used. Use-wear was observed on ten small celts and six very small celts. All appear to be too small to have been used for land-clearing. Most of the used celts were probably employed in wood carving or fine woodworking tasks. While the mean length-to-width ratio of the unused celts is $1.9(\mathrm{SD}=0.4$, range $=1.1-2.9, \mathrm{~N}=50)$, that of the used celts is $1.5(\mathrm{SD}=0.2$, range $=1.3-1.9, \mathrm{~N}=15)$, suggesting that most of the used celts are shorter than the unused celts (Figure 10). The used celts included recycled celts that are vertically shorter due to the reshaping of broken distal ends. In summary, all large and medium celts, as well as most of the small and very small celts, were ritual objects rather than utilitarian tools.

\section{Conclusion}

Microwear analysis, conducted using high-power microscopy, has elucidated the use of the Preclassic polished greenstone celts to a degree that was not previously possible. The results indicate that most polished celts were not utilitarian tools, but rather ritual objects intended 
for deposition during public rituals. Those that had been used were employed for wood carving before also being deposited in caches in a similar manner.

The deposits of greenstone celts at Ceibal reflect the adoption of earlier ritual traditions, particularly those of greenstone celts of the Early Preclassic Gulf Coast inhabitants, and the innovation of new concepts and practices. Cruciform caches began to emerge during the Real 1 phase (1000-850 BC), and spread widely from La Venta, the Chiapas Grijalva River basin and the Maya lowlands during the Real 3 and Escoba 1 phases (775-600 BC). These deposits probably indicate a growing emphasis on the directional symbolism tied to the movement of the sun. Although it remains unclear whether platform Ch'och' was an elite residential complex during the Real 1 and 2 phases, the offerings of pectorals and other personal ornaments, along with greenstone celts, suggests the presence of emerging elites, who probably played an important role in the exchange, production, use and public ritual deposition of greenstone celts, including securing the raw materials from which they were made.

The excavation by Daniela Triadan shows that by the Real 3 phase, another large complex, platform K'at, came to serve as a residential compound for these elites (Triadan et al. in press). Repeated performance of public rituals throughout the Middle Preclassic period, along with collaborative construction projects, probably facilitated social integration and group identity while allowing negotiations and contests among community members (Inomata 2014). The emerging elites at Ceibal were probably actively engaging with concepts associated with cardinal directions and the Maya cosmos during the Middle Preclassic period. The Preclassic format of public interaction was closely followed by descendants during the Classic period, with rulers taking centre stage. Hence not only factors such as interregional exchange, but also ideology, expressed in material form and through aspects of public rituals and public ceremonial structures, played a significant role in the development of Maya rulership.

\section{Acknowledgements}

Funding for our research was provided by the National Endowment for the Humanities (RZ-51209-10), the Alphawood Foundation and the Japan Society for the Promotion of Science (Grants-in-Aid for Scientific Research 21101003, 21402008, 26101003 and 26300025). We greatly appreciate the significant improvements to the manuscript suggested by the editor and two peer reviewers, E. Wyllys Andrews and Zachary Hruby. We would also like to thank the members of the Ceibal-Petexbatun Archaeological Project, particularly Daniela Triadan, Otto Román, Víctor Castillo and Estela Pinto for their guidance and support during our study.

\section{References}

Aoyama, K. 1999. Ancient Maya state, urbanism, exchange, and craft specialization: chipped stone evidence from the Copan Valley and the La Entrada Region, Honduras (Memoirs in Latin American Archaeology 12). Pittsburgh (PA): University of Pittsburgh.

- 2009. Elite craft producers, artists, and warriors at Aguateca: lithic analysis (Monographs of the Aguateca Archaeological Project First Phase Volume 2). Salt Lake City: The University of Utah Press.
Bachand, B. 2013. Las fases Formativas de Chiapa de Corzo: nueva evidencia e interpretaciones. Estudio de Cultura Maya XLII: 11-52. https://doi.org/10.1016/S0185-2574(13)71385-6

Drucker, P., R. Heizer \& R. Squier. 1959. Excavations at La Venta, Tabasco, 1955 (Bulletin 170). Washington, D.C.: Smithsonian Institution Bureau of American Ethnology.

Estrada-Belli, F. 2006. Lightning sky, rain, and the maize god: the ideology of Preclassic Maya rulers at Cival, Peten, Guatemala. Ancient Mesoamerica 17: 57-78.

https://doi.org/10.1017/S0956536106060068 


\section{Polished greenstone celt caches from Ceibal}

Inomata, T. 2014. Plaza builders of the Preclassic Maya lowlands: the construction of a public space and a community at Ceibal, Guatemala, in K. Tsukamoto $\&$ T. Inomata (ed.) Mesoamerican plazas: arenas of community and power: 19-33. Tucson: University of Arizona Press.

Inomata, T. \& D. Triadan. 2016. Middle Preclassic caches from Ceibal, Guatemala. Maya Archaeology 3: 56-91.

Inomata, T., D. Triadan, K. Aoyama, V. Castillo \& H. Yonenobu. 2013. Early ceremonial constructions at Ceibal, Guatemala, and the origins of lowland Maya civilization. Science 340: 467-71. https://doi.org/10.1126/science.1234493

Inomata, T., J. MacLellan, D. Triadan, M. Burham, K. Aoyama, H. Nasu, J. Munson, F. Pinzón \& H. Yonenobu. 2015. Development of sedentary communities in the Maya lowlands: co-existing mobile groups and public ceremonies at Ceibal, Guatemala. Proceedings of the National Academy of Sciences of the USA 112: 4268-73. https://doi.org/10.1073/pnas.1501212112

Lowe, G. 1981. Olmec horizons defined in mound 20, San Isidro, Chiapas, in E. Benson (ed.) The Olmec and their neighbors: 231-55. Washington, D.C.: Dumbarton Oaks Research Library and Collection.

Miller, M. \& K. Taube. 1993. An illustrated dictionary of the gods and symbols of ancient Mexico and the Maya. London: Thames \& Hudson.

Ortiz, P. \& M. Rodríguez. 2000. The sacred hill of El Manatí: a preliminary discussion of the site's ritual paraphernalia, in J. Clark \& M. Pye (ed.) Olmec art and archaeology in Mesoamerica: 75-93. Washington, D.C.: National Gallery of Art.

SABloff, J.A. 1975. Excavations at Seibal, department of Peten, Guatemala: ceramics (Peabody Museum Memoirs 13). Cambridge (MA): Peabody Museum, Harvard University.
Seitz, R., G.E. Harlow, V.B. Sisson \& K.A. Taube. 2001. 'Olmec blue' and Formative jade sources: new discoveries in Guatemala. Antiquity 75: 687-88. https://doi.org/10.1017/S0003598X00089171

Sмiтh, A.L. 1982. Excavations at Seibal, department of Peten, Guatemala: major architecture and caches (Peabody Museum Memoirs 15). Cambridge (MA): Peabody Museum, Harvard University.

TAKase, K. 2007. Use-wear analysis on replicated stone axes used in the experimentation: examinations by the high-power methods. Tokyo Metropolitan University occasional papers of archaeology 11, reports of human action and society 2005-research of the life in Hida Gorge and experimental archaeology: 65-113 (in Japanese with English title). Hachiooji: Tokyo Metropolitan University Archaeology Laboratory.

Taube, K. 2000. Lightning celts and corn fetishes: the Formative Olmec and the development of maize symbolism in Mesoamerica and the American Southwest, in J. Clark \& M. Pye (ed.) Olmec art and archaeology in Mesoamerica: 297-337. Washington, D.C.: National Gallery of Art.

Triadan, D., V. Castillo, T. Inomata, J.M. Palomo, M.B. Méndez, M. Córtave, J. Maclellan, M. Burham \& E. Ponciano. In press. Power and social relations in a Middle Preclassic community: elite residential complexes at Ceibal. Ancient Mesoamerica 28.

Willey, G. 1990. Excavations at Seibal, department of Peten, Guatemala: general summary and conclusions (Peabody Museum Memoirs 17). Cambridge (MA): Peabody Museum, Harvard University.

YAMADA, S. 2014. Use-wear analysis of axes: a review. A paper presented at the $19^{\text {th }}$ Suyanggae International Symposium 'Suyanggae and her Neighbours in Poland', Lodz, Poland, 22-27 June 2014.

Received: 12 February 2016; Accepted: 10 May 2016; Revised: 18 May 2016 